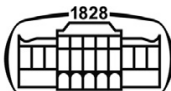

AKADÉMIAI KIADÓ

\title{
CORRIGENDUM: THE IMMORTALITY KEY: THE SECRET HISTORY OF THE RELIGION WITH NO NAME
}

\section{Journal of Psychedelic Studies}

$5(2021) 1,56$

DOl:

$10.1556 / 2054.2021 .20000$

(c) 2021 The Author(s)

\section{CORRIGENDUM}
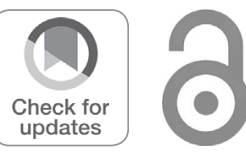

Corresponding author
JERRY B. BROWN* $\odot$

Global and Sociocultural Studies, Florida International University, Miami, FL, USA

Journal of Psychedelic Studies

DOI: $10.1556 / 2054.2021 .00170$

The above paper should be modified as follows:

1. The name of Albert Hofmann has been misspelt as Hoffman: in paragraph 5, line 1, and in paragraph 6 , line 2 of the article.

2. There is a misquote of Muraresku in the section: The Religion has a Name: "Shamanism" in Paragraph 2 (under the section title), in line 8:

The quote currently reads: "Lying down in a cave for a few days might get the job done,"

The correct quote is: "Lying down in a cave for a few days will certainly get the job done,"

3. In References, there has been a typo:

In the journal name Eleusis, the " $u$ " in the text should be replaced with an "i," as follows:

Samorini, G. (1998). "Mushroom-trees in Christian art.” Eleusis, 8:30-37.

The Author

Open Access. This is an open-access article distributed under the terms of the Creative Commons Attribution-NonCommercial 4.0 International License (https://creativecommons.org/licenses/by-nc/4.0/), which permits unrestricted use, distribution, and reproduction in any medium for non-commercial purposes, provided the original author and source are credited, a link to the CC License is provided, and changes - if any - are indicated. 